\title{
Pengaruh Model Problem Based Learning terhadap Kemampuan Berpikir Tingkat Tinggi Siswa SMA
}

\author{
Azni Fajrilia $^{1}$, Budi Handoyo ${ }^{1}$, Dwiyono Hari Utomo ${ }^{1}$ \\ ${ }^{1}$ Pendidikan Geografi-Universitas Negeri Malang
}

\begin{tabular}{l}
\hline INFO ARTIKEL \\
\hline Riwayat Artikel: \\
Diterima: $31-07-2019$ \\
Disetujui: $14-10-2019$ \\
\hline
\end{tabular}

\section{Kata kunci:}

problem based learning; higher-order thinking skills; high school student; problem based learning; kemampuan berpikir tingkat tinggi; siswa SMA

\begin{abstract}
ABSTRAK
Abstract: Problem based learning is a learning model that focuses on students and is contextual in nature. Students are directly involved in finding a solution to a problem, so that the model is able to improve high-level thinking skills. The purpose of this study is to see the effect of the problem based learning model on high-level thinking skills of high school students. The research design applied was quasi experiment. The subjects in this study consisted of two classes namely class XI MIPA 4 as ekpeimmen class and XI Language as control class. The study was conducted at MAN Kota Batu in 2019. The data analysis used is the independent sample t-test which shows the effect that is proven by the significance of $<0.05$ that is 0,000 so that the two variables are declared influential.

Abstrak: Problem based learning merupakan model pembelajaran yang berfokus kepada siswa dan sifatnya kontekstual. Siswa terlibat langsung untuk mencari jalan keluar suatu masalah sehingga model tersebut mampu meningkatkan kemampuan berpikir tingkat tinggi. Tujuan dari penelitian ini yaitu untuk melihat pengaruh model problem based learning terhadap kemampuan berpikir tingkat tinggi siswa SMA. Rancangan penelitian yang diterapkan adalah eksperimen semu. Subjek dalam penelitian ini terdiri dari dua kelas yaitu kelas XI MIPA 4 sebagai kelas eksperimen dan XI Bahasa sebagai kelas kontrol. Penelitian dilakukan di MAN kota Batu pada tahun 2019. Analisis data yang dipergunakan adalah uji independent sample t-test yang menunjukkan adanya pengaruh yang dibuktikan dengan signifikansi $<0,05$ yaitu 0,000 sehingga dari kedua variabel dinyatakan berpengaruh.
\end{abstract}

\section{Alamat Korespondensi:}

Azni Fajrilia

Pendidikan Geografi

Universitas Negeri Malang

Jalan Semarang 5 Malang

E-mail: aznfajrilia@gmail.com

Pembelajaran berbasis masalah adalah pembelajaran yang bersifat kontekstual. Siswa belajar dengan lingkungan sekitar yang dapat mereka lihat secara nyata. Sesuai dengan pendapat (Fathurrohman, 2015) proses belajar yang menggunakan masalah secara nyata dapat mengembangkan kemampuan siswa agar berpikir dan membangun pengetahuan ataupun ide-ide yang baru. Dimana pemecahan masalah bisa meningkatkan aktivitas siswa dan dapat mentransfer pengetahuan mereka di kehidupan yang nyata (Miswar \& Yarmaidi, 2016). Problem based learning mengajak siswa untuk berpikir secara tingkat tinggi, dimana siswa mencari tahu sendiri solusi untuk pemecahan masalah. Fokus utama pada Problem based learning adalah masalah yang dijadikan sebagai alat dalam pembelajaran yang digunakan untuk mengembangkan keterampilan dalam mencari solusi yang tepat (Purwanto, Djatmika, \& Hariyono, 2016). Jadi, problem based learning sesuai dengan materi mitigasi bencana alam karena mempelajari tentang kerusakan alam yang terjadi di sekeliling lingkungan siswa. Adapun kelebihan problem based learning dibandingkan dengan model pembelajaran yang lain yaitu dianggap lebih menyenangkan dan disukai oleh siswa karena dapat meluaskan kemampuan berpikir kritis dimana hal tersebut termasuk bagian dari kemampuan berpikir tingkat tinggi (Miswar \& Yarmaidi, 2016).

Ada lima tahapan dalam melakukan eksperimen dengan model problem based learning yang dipaparkan oleh (Sumarmi, 2015), meliputi (1) pengarahan siswa pada permasalahan yang bertujuan memberikan pancingan awal yang disajikan berupa gambar dan video tentang daerah rawan bencana alam; (2) memberikan masukan kepada siswa supaya belajar yang bertujuan untuk membagi-bagi tugas yang berhubungan dengan masalah yang didapatkan kelompok masing-masing; (3) memberikan arahan kepada setiap kelompok yang tujuannya untuk mendorong siswa supaya mencari informasi dan menemukan solusi dari peristiwa bencana alam; (4) penyajian laporan yang merupakan karya dari kelompok yang tujuannya untuk menemukan jawaban atas informasi yang telah dikumpulkan dengan melakukan presentasi dan diskusi kelompok. Diskusi dilakukan supaya mampu meningkatkan kemampuan siswa dalam pemecahan masalah (Pramono, 2012); (5) menganalisis dan mengevaluasi masalah bertujuan untuk mencari kesimpulan atau titik temu dari pendapat siswa untuk dievaluasi dan guru memberikan penjelasan agar siswa paham. 
Pelaksanaan model problem based learning dilakukan secara berkelompok yang terdiri dari enam kelompok. Setiap kelompok memiliki tema permasalahan yang berbeda-beda yang bertujuan untuk mempelajari jenis-jenis bencana alam dan disesuaikan dengan lingkungan sekitar. Kemampuan berpikir tingkat tinggi pada saat ini menjadi prioritas dalam proses pembelajaran. Menurut (BSNP, 2010) keahlian yang harus dimiliki pada saat ini salah satunya yaitu kemampuan untuk berpikir kritis. Kemampuan tersebut termasuk ke dalam berpikir tingkat tinggi yang terdapat beberapa tahapan yaitu menganalisis, mengevaluasi, dan mengkreasi. Tahap menganalisis atau dalam ranah kognitif termasuk ke dalam C4, siswa melakukan analisis ketika diperintahkan oleh guru untuk mencari solusi dari masalah-masalah yang timbul dengan cara mencari tahu informasi yang relevan. Tahap mengevaluasi (C5) dimana guru menjadi penengah atas pendapat dari semua siswa, pada saat ini guru dan siswa menyamakan pendapat dan guru meluruskan serta memilih satu jawaban yang terbaik. Tahapan selanjutnya adalah mengkreasi (C6) salah satu karakteristiknya menciptakan jalan berpikir baru yang belum pernah dilakukan dari yang sebelumnya. Dari ketiga tahapan tersebut dapat dilihat apakah siswa sudah mampu untuk berpikir tingkat tinggi atau masih berpikir dengan tingkat yang rendah.

Siswa yang biasa berperan dalam proses pembelajaran mempunyai kemampuan berpikir tingkat tinggi. Berperan memiliki arti bahwa tidak hanya sekedar berpendapat secara umum atau yang bersifat hafalan saja, tetapi kemampuan siswa untuk berpikir secara mendalam dan bermakna sehingga dapat dipahami. Hal tersebut lebih memungkinkan adanya interaksi antar siswa dan guru yang dapat terbina secara maksimal (Widyaningsih \& Rosidi, 2015). Dengan hal yang seperti itu akan menghasilkan ide-ide untuk pemecahan masalah. Hal lainnya mengapa dilakukan eksperimen pada materi mitigasi bencana alam karena mitigasi bencana cocok dan sesuai dengan sintak dari model problem based learning. Berdasarkan uraian di atas, diperlukan eksperimen model problem based learning untuk melihat berpengaruh atau tidaknya terhadap kemampuan berpikir tingkat tinggi siswa SMA di MAN kota Batu.

\section{METODE}

Rancangan penelitian yang digunakan adalah quasy eksperiment (eksperimen semu) dengan pretest (kemampuan awal) posttest (kemampuan akhir) control group desain. Pretest untuk melihat pengetahuan awal siswa sebelum digunakannya model berbasis masalah pada kelas eksperimen dan kontrol. Posstest dilakukan untuk melihat kemampuan akhir siswa setelah pembelajaran menggunakan model problem based learning pada kelas eksperimen dan kontrol. Teknik pengambilan data memakai soal tes esai sebanyak lima soal dan tes soal pilihan ganda sebanyak sepuluh soal. Soal telah diuji validitas dan reliabilitasnya. Subjek penelitian di kelas eksperimen diperlakukan dengan model problem based learning di kelas XI MIPA dan secara konvensional di XI Bahasa di MAN kota Batu tahun ajaran 2017/2018. Penjabaran data yang dilakukan pertama kali yaitu uji normalitas dengan kolmogrof Smirnov dan uji homogenitas untuk diketahui apakah soal normal dan homogen. Selanjutnya yaitu uji hipotesis memakai uji T menggunakan SPSS 21 dengan ketentuan nilai probabilitas harus kurang dari 0,05 maka data tersebut signifikan. Jika data lebih dari 0,05 maka tidak signifikan dan tidak ada pengaruh antar kedua variabel penelitian.

\section{HASIL}

Hasil analisis data menggunakan uji t memperlihatkan bahwa penelitian tersebut berpengaruh di MAN kota Batu. Untuk mengetahui pengaruh antar kedua variabel tersebut, maka dilakukan pengolahan data berupa pretest, posttets, gain score, dan uji t, soal yang digunakan adalah lima soal esai dan sepuluh soal pilihan ganda.

Langkah selanjutnya adalah mencari nilai gain score dari kelas yang di eksperimenkan dan kontrol. Gain score didapatkan dari perbedaan antara nilai awal dan nilai akhir. Jadi, terlihat rerata nilai awal, akhir, dan perbedaan dari variabel kemampuan berpikir tingkat tinggi pada tabel 1.

Tabel 1. Rata-Rata Nilai Pretest, Posttest, dan Gain Score Kemampuan Berpikir Tingkat Tinggi

\begin{tabular}{lccl}
\hline \multicolumn{1}{c}{ Kelas } & $\begin{array}{c}\text { Rata-Rata Jumlah } \\
\text { Pretest }\end{array}$ & $\begin{array}{c}\text { Rata-Rata Jumlah } \\
\text { Posttest }\end{array}$ & $\begin{array}{c}\text { Rata-Rata Jumlah } \\
\text { Gain Score }\end{array}$ \\
\hline Eksperimen & 62,38 & 82,95 & 20,60 \\
Kontrol & 61,11 & 68,76 & 7,65 \\
\hline
\end{tabular}

Dapat diketahui pada tabel 1 yang memperlihatkan perbedaan rerata nilai sebelum dan setelah diberikan perlakuan untuk kelas eksperimen dan kontrol. Kelas eksperimen mempunyai jumlah rata-rata pretest 62,38 makin besar dari pretest kelas kontrol sebanyak 61,11. Kedua nilai pretest tidak terlalu jauh untuk kedua kelas tersebut. karena rata-rata jumlah posttest untuk kelas eksperimen lebih tinggi yaitu 82,95 dan untuk kelas kontrol rata-rata nilai posstestnya 68,76. Hal itu menandakan rata-rata poin posttest lebih tinggi kelas eksperimen dengan selisih yang cukup jauh. Dengan demikian, rerata gain score yang didapatkan kelas eksperimen semakin meningkat ketimbang kelas kontrol yang ditandai pada rata-rata gain score kelas eksperimen 20,60, sedangkan kelas kontrol hanya 8,65 saja. Berikut adalah gambar 1 untuk melihat lebih jelas rata-rata nilai pretetst, posttest, dan gain score (selisih). 


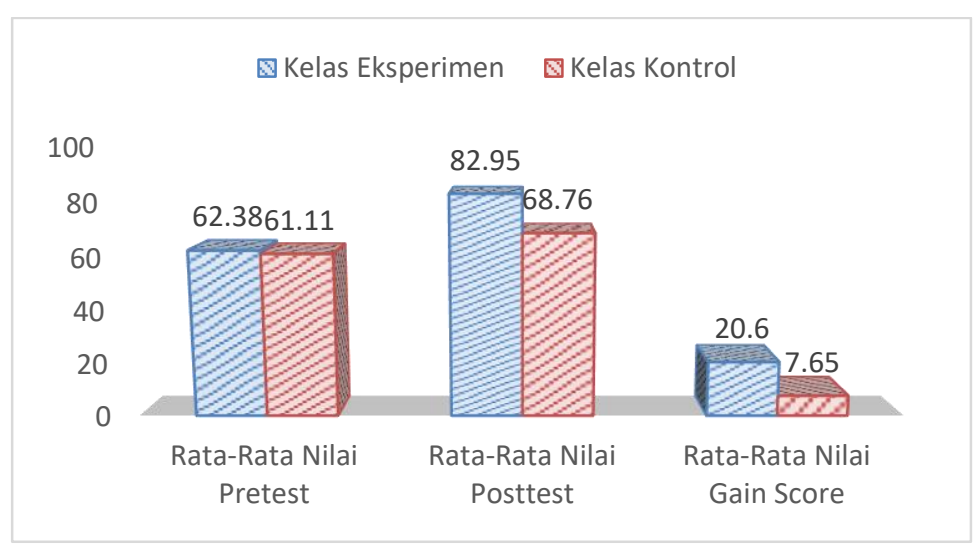

\section{Gambar 1. Menunjukkan Rerata Nilai Pretest, Posttest, dan Gain Score Berpikir Tingkat Tinggi}

Berdasarkah gambar 1, penelitian dinyatakan berpengaruh dilihat pada nilai pretest dan posttest pada setiap kelas. Tahap selanjutnya adalah melakukan uji analisis yang menggunkan uji T-test, sebagaimana tabel 2.

Tabel 2. Hasil Analisis Uji T

\begin{tabular}{llccccr}
\hline & & \multicolumn{2}{c}{$\begin{array}{c}\text { Levene's test for equality } \\
\text { of variances (ltfeov) }\end{array}$} & \multicolumn{3}{c}{$\begin{array}{c}\text { T-test for equality } \\
\text { of means (tfeom) }\end{array}$} \\
\hline \multirow{2}{*}{ Gain score } & F & Sign. & T & Df & Sig. (2-tailed) \\
& Equal variances assumed $(E V A)$ & 1,858 &, 177 & 6,673 & 67 &, 000 \\
& Equal variances not assumed $($ EVNA) & & & 6,597 & 59,919 &, 000 \\
\hline
\end{tabular}

Tabel 2 menunjukkan adanya ikatan antara model dengan kemampuan berpikir tingkat tinggi dengan nilai signifikansi 0,000 yang artinya $<0,05$ dan dapat dikatakan signifikan. Kelas eksperimen dan kontrol sama-sama mempunyai signifikansinya 0,000 .

\section{PEMBAHASAN}

Bersumber hasil penelitian, dapat dilihat nilai (awal) pretest, (akhir) posttest, dan (selisih) gain score pada kelas eksperimen atau dari kontrol. Kelas eksperimen memiliki nilai pengetahuan awal dan akhir yang berbeda dengan kelas kontrol. Pada umumnya, angka pretest kelas eksperimen sebesar 63,38 dan rata-rata pretest untuk kelas kontrol sebanyak 61,11 sehingga bedanya nilai pretest pada kedua kelas tersebut sebesar 1,27. Rata-rata nilai posttest kelas eksperimen sebesar 82,95 dan kelas kontrol 68,76 sehingga selisih kedua kelas sebesar 14,19. Dengan adanya data ini dapat diperhatikan nilai untuk pretest maupun posstest dari kelas eksperimen dinyatakan lebih tinggi dari kelas kontrol.

Selain nilai pretest dan posstest terdapat nilai gain score yang menunjukkan selisih pada grup eksperimen lebih tinggi dibandingkan dengan selisih dari kelas yang diperlakukan biasa. Gain score kelas eksperimen sebesar 20,60, sedangkan gain score kelas kontrol hanya 7,65 saja. Hal tersebut menunjukkan penerapan model berbasis masalah (problem based learning) digunakan buat mengukur kemampuan berpikir tinggi dinyatakan berpengaruh untuk kelas eksperimen. Berbeda buat kelas kontrol yang mengenakan model konvensional yang memiliki pengaruh, tetapi tidak sebagus kelas eksperimen.

Berdasarkan hasil uji statistik menunjukkan bahwa terdapat efek yang relevan antara model problem based learning terhadap kemampuan berpikir tingkat tinggi. Hal tersebut dibuktikan dengan data analisis menggunakan Uji T-test nilai signifikansinya 0,000 untuk kelas eksperimen sehingga dapat diartikan bahwa signifikansi $<0,05$ dan kelas eksperimen dinyatakan berpengaruh antara model pembelajaran dan kemampuan berpikir tingkat tinggi siswa pada kelas XI MIPA 4. Penelitian dilakukan sebanyak tiga kali tatap muka untuk menerapkan model problem based learning dan ditambah dua kali pertemuan untuk melakukan pretetst dan posstest. Sebelum melakukan pretetst dan posttest di kelas eksperimen dan kontrol, dilakukan dulu uji coba soal pada kelas XII IPS yang sebelumnya telah menempuh materi mitigasi bencana alam saat mereka masih kelas XI. Uji coba soal dilakukan untuk melihat apakah soal tersebut telah valid dan sudah reliabel. Jika sudah valid dan reliabel maka soal itu layak untuk dipergunakan dan diujicobakan dalam penelitian eksperimen.

Pada proses pembelajaran model yang dipergunakan mampu meningkatkan cara berpikir pada siswa. Adanya hal tersebut dibuktikan dengan keaktifan siswa pada saat mengemukakan pendapat dalam memecahkan masalah dari materi mitigasi bencana alam. Materi mitigasi bencana alam sesuai dengan lingkungan sekitar siswa baik sekolah maupun tempat tinggal. Materi bencana alam yang diambil adalah tanah longsor, banjir, angin puting beliung, dan kebakaran hutan yang terjadi di kota Batu dan kota 
Malang. Materi tersebut telah disesuaikan dengan jenis-jenis bencana alam, seperti akibat dari bencana geologis, klimatologis, dan ektrateristrial. Materi pembelajaran disajikan dalam bentuk gambar dan video sehingga pembelajaran bersifat kontekstual. Hal tersebut berperan penting karena model dan media pembelajaran yang dipakai dapat melatih kemampuan berpikir tingkat tinggi siswa (Diani, Asyhari, \& Julia, 2018).

Kesesuaian materi mitigasi bencana alam dengan model pembelajaran yang dipergunakan supaya dapat meningkatkan kemampuan berpikir tinggi pada siswa. Pembelajaran tersebut dilakukan secara berkelompok yang terdiri dari enam kelompok dan dipilih secara acak. Contohnya indikator pertama dalam model PBL (problem based learning) adalah memfokuskan siswa pada permasalahan, dimana mereka diberikan gambar dan video sebagai stimulus awal untuk merangsang pemikiran siswa agar mengidentifikasi masalah yang ditunjukkan. Para siswa terpacu untuk berpikir tingkat tinggi untuk mengumpulkan informasi yang dibutuhkan (Sujiono, Budi Handoyo, 2018). Menurut (Sari, Budijanto, \& Amiruddin, 2017) masalah yang ditemukan memiliki karakteristik, yaitu (1) autentik, dimana permasalahan harus sesuai dengan kenyataan yang ada, (2) jelas, artinya masalah yang dirumuskan harus jelas sehingga tidak menyulitkan siswa dalam proses mencari solusi, (3) gampang paham, yaitu kasus yang disajikan harus dapat dimengerti oleh siswa yang setara dengan kemampuan mereka, (4) leluasa dan serasi dengan tujuan pembelajaran yaitu harus mewakili semua materi pembelajaran yang ada, misalnya dapat menjelaskan mitigasi bencana alam sesuai dengan sumber yang tersedia, dan (5) bermanfaat, yaitu permasalahan tersebut nantinya harus bermanfaat bagi siswa, dengan adanya masalah ketika sudah menemukan solusi yang tepat dan solusi tersebut bermanfaat bagi siswa itu sendiri. Langkah kedua yaitu mengumpulkan siswa agar belajar, saat ini siswa mendefinisikan masalah dari tahap sebelumnya.

Langkah selanjutnya adalah membimbing investigasi perseorangan atau kelompok, saat siswa diperintahkan guru supaya mencari informasi sebanyak-banyaknya untuk menyelesaikan masalah mitigasi bencana alam yang telah disajikan guru dalam bentuk video. Ketika siswa telah mendapatkan informasi yang cukup, siswa masuk ke dalam tahap menganalisis dimana menganalisis adalah salah satu indikator untuk kemampuan berpikir tingkat tinggi. Pada langkah ini siswa mulai menggunakan pengetahuannya untuk menganalisis, dimana setiap anggota kelompok mempunyai pendapat yang berbeda-beda. Menganalisis informasi yang masuk dan mencari tahu faktor penyebab dan apa saja akibat yang ditimbulkan dari bencana alam serta didiskusikan dengan anggota kelompok sehingga dapat menyimpulkan jawaban yang sesuai dengan pemikiran dari kelompok tersebut. Dengan demikian, problem based learning membawa siswa aktif sehingga pembelajaran menjadi lebih berkesan dan mempunyai manfaat yang tinggi (Pramono, 2018).

Selanjutnya adalah menyajikan hasil dari infomasi yang siswa temukan yang dibuat dalam bentuk laporan. Langkah ini siswa mempresentasikan hasil dan berdiskusi dengan kelompok lainnya, ada yang memberi sanggahan, dan masukan. Pada langkah ini siswa aktif dan saling berinteraksi guna mengemukakan solusi dari permasalahan bencana alam. Langkah ini pada indikator kemampuan berpikir tingkat tinggi adalah mengevaluasi, dimana siswa bebas memberikan tanggapan, ide-ide baru, ataupun sanggahan atas jawaban dari kelompok yang lain. Langkah ini membuat siswa aktif dan mampu menggali kemampuan berpikir terutama berpikir tingkat tinggi (Marliana, 2017). Selanjutnya, siswa menganalisis dan mengevaluasi proses pemecahan massalah, dimana guru memberikan penjelasan terkait jawaban dan sanggahan yang telah siswa kemukakan. Pada langkah ini guru membantu siswa untuk menyimpulkan dari hasil diskusi siswa dimana langkah mengkreasi di berpikir tingkat tinggi terlaksana seperti membuat ide atau cara pandang yang sama dari permasalahan bencana alam yang siswa analisis sebelumnya.

Kemampuan berpikir tingkat tinggi dapat terbentuk ketika proses pembelajaran berlangsung dan pembelajaran tersebut berpusat pada siswa. Proses yang seperti itu siswa bebas dalam mengemukakan pendapat sesuai dengan pengetahuan yang mereka punya dengan materi pembelajaran yang kontekstual, atau yang sering mereka jumpai bencana alam, bahkan ada siswa yang pernah mengalami salah satu bencana alam tersebut. Jadi, materi pembelajaran yang digunakan sangat kontekstual dan sesuai dengan strategi pencapaian untuk masa yang akan datang (BSNP, 2010).

Pembelajaran yang kontekstual diyakini dapat meningkatkan kemampuan siswa dalam berpikir, dimana siswa mendapatkan ide-ide dan pengetahuan yang baru, dengan adanya hal tersebut secara tidak langsung kemampuan berpikir tingkat tinggi siswa muncul dan terlatih. Permasalahan yang kontekstual dapat digunakan untuk mengeksplorasi pengetahuan sebagai proses pembelajaran (Zainuddin, Budijanto, \& Amirudin, 2016). Adapun kemampuan berpikir tingkat tinggi yang dapat dicapai antara lain menganalisis diartikan sebagai kemampuan siswa untuk memilih komponen-komponen dari permasalahan dan memberikan pendapat terkait pendapat tersebut (Kurniati, 2016). Selanjutnya, mengevaluasi yang berarti membuat suatu keputusan berdasarkan pada kriteria biasanya memeriksa dan mengkritik suatu pernyataan (Annuuru, Johan, \& Ali, 2017). Berikutnya adalah kreasi yang diartikan sebagai kemampuan siswa dalam mengombinasikan bagian-bagian untuk membentuk, merancang sesuatu yang baru (Nisa, Nadiroh, \& Siswono, 2018). Kegiatan seperti itu dilakukan dan dikerjakan oleh siswa, disini guru hanya sebagai fasilitator saja dan menyimpulkan ketika proses diskusi telah berakhir. 


\section{SIMPULAN}

Simpulan dari penelitian ini terlihat bahwa ada hasil yang signifikan model problem based learning terhadap kemampuan berpikir tingkat tinggi dengan materi mitigasi bencana alam yang dieksperimenkan di kelas XI MIPA 4 di MAN Kota Batu. Hal tersebut dinyatakan berhasil karena nilai kemampuan berpikir tingkat tinggi di kelas eksperimen bertambah tinggi daripada nilai kelas kontrol karena yang digunakan yaitu model konvensional.

Saran untuk guru supaya penggunaan soal-soal latihan ataupun untuk ujian berpacu pada indikator berpikir tingkat tinggi guna melatih kemampuan siswa dalam berpikir. Tidak hanya materi mitigasi bencana alam saja, kemampuan berpikir tingkat tinggi siswa juga dapat digunakan pada materi pembelajaran Geografi yang lain. Saran untuk penelitian selanjutnya supaya lebih memperhatikan kemampuan setiap siswa dan dapat menambahkan variabel yang lain.

\section{DAFTAR RUJUKAN}

Annuuru, T. A., Johan, R. C., \& Ali, M. (2017). Peningkatan Kemampuan Berpikir Tingkat Tinggi Dalam Pelajaran Ilmu Pengetahuan Alam Peserta Didik Sekolah Dasar melalui Model Pembelajaran Treffinger. Educational Technologia, 1(2), 136-144.

Diani, R., Asyhari, A., \& Julia, O. N. (2018). Pengaruh Model RMS (Reading, Mind Mapping, and Sharing) terhadap Kemampuan Berpikir Tingkat Tinggi Siswa pada Pokok Bahasan Impuls dan Momentum. Jurnal Pendidikan Edutama, 5(1), 31. https://doi.org/10.30734/jpe.v5i1.128

Kurniati, D. (2016). Kemampuan Berpikir Tingkat Tinggi Siswa SMP. Kemampuan Berpikir Tingkat Tinggi Siswa SMP, 20(2), $142-155$.

Marliana, M. (2017). Peningkatan Higer Order Thinking Skills (HOTS) menggunakan Model Pembelajaran Problem Based Learning (PBL) di Kelas X IPS 1 SMAN 1 Pulau Laut Tengah. Tesis tidak diterbitkan. Universitas Negeri Malang, Malang.

Miswar, D., \& Yarmaidi, E. S. (2016). Perbedaan Penerapan Model Problem Based Learning pada Hasil Belajar Geografi. Yogyakarta: Media Akademi.

Nisa, N. C., Nadiroh, N., \& Siswono, E. (2018). Kemampuan Berpikir Tingkat Tinggi (HOTS) tentang Lingkungan Berdasarkan Latar Belakang Akademik Siswa. Jurnal Ilmiah Pendidikan Lingkungan dan Pembangunan, 19(2), 1-14. https://doi.org/10.21009/plpb.192.01

Pramono, S. E. (2012). Perbaikan Kesalahan Konsep Pembelajaran Sejarah melalui Metode Pemecahan Masalah dan Diskusi. Paramita: Historical Studies Journal, 22(2). https://doi.org/10.15294/paramita.v22i2.2124

Pramono, S. E. (2018). Pengaruh Model Problem Based Learning terhadap Keterampilan Geografi. Jurnal Pendidikan: Teori, Penelitian, dan Pengembangan, 3(10), 1391-1397. https://doi.org/10.17977/jptpp.v3i10.11738

Purwanto, W., Djatmika, E. T., \& Hariyono. (2016). Penggunaan Model Problem Based Learning dengan Media Powerpoint untuk Meningkatkan Minat Belajar Siswa. Jurnal Pendidikan: Teori, Penelitian, dan Pengembangan, 1(9), 1700-1705.

Sari, N. P., Budijanto, B., \& Amiruddin, A. (2017). Pengaruh Penerapan Model Pembelajaran Problem Based Learning Dipadu Numbered Heads Together terhadap Keterampilan Metakognitif dan Kemampuan Berpikir Kritis Geografi Siswa SMA. Jurnal Pendidikan: Teori, Penelitian, dan Pengembangan, 2(3), 440-447.

Sujiono, Budi Handoyo, I. N. R. (2018). Memecahkan Masalah Geografi melalui Problem Based Learning. Jurnal Teori dan Praksis Pembelajaran IPS, 2(2), 66-72. https://doi.org/10.17977/um022v2i22017p072

Sumarmi, S. (2015). Model-Model Pembelajaran Geografi. Yogyakarta: Aditya Media Publishing.

Widyaningsih, S., \& Rosidi, I. (2015). Pengaruh Pembelajaran Aktif terhadap Hasil Belajar Siswa pada Materi Pokok Plantae. Jurnal Pena Sains, 2(2), 112-119.

Zainuddin, M., Budijanto., \& Amirudin, A. (2016). Pengaruh Model Problem Based Learning dengan Pendekatan Inquiry terhadap Hasil Belajar Siswa SMA. Jurnal Pendidikan: Teori, Penelitian, dan Pengembangan, 1(12), 2359-2364. 